\title{
Application of Triethyl Citrate to Filters in Virginia Type Cigarettes *
}

\author{
by \\ Yong Jin, Saibo Yu, Qi Liu, Shitai Wang, Haifeng Tan, Ke Li, Hongmei Fan \\ Technology Center, China Tobacco Hunan Industry Co. Ltd., Changsha 410007, P.R. China
}

\section{SUMMARY}

Triethyl citrate (TEC) was applied in the preparation of cigarette filter rods by two approaches. One was to utilize TEC as a plasticizer sprayed onto the surface of cellulose acetate (CA) fibers. The other was to apply TEC as an additive coated onto the cellulosic paper of acetate-paper dual filters. Three types of cigarette filter rods, namely, triethyl citrate-cellulose acetate (TEC-CA) filter rods, triethyl citrate-cellulose acetate-paper (TEC-CA-paper) dual filter rods and cellulose acetate-paper-triethyl citrate (CA-paper-TEC) dual filter rods, were manufactured. In order to promote the curing of CA rods, high-frequency radiation was introduced into the procedure of filter manufacture. Then Virginia type cigarettes, combined with the three kinds of prepared filter rods were manufactured and the removal efficiency of phenols from the cigarette mainstream smoke was investigated. The results revealed that no matter where the triethyl citrate was applied as plasticizer or coating additive, the content of phenol, $o-, m$ and $p$-cresol in cigarette mainstream smoke could be greatly reduced. The optimal removal efficiency for phenol was $50 \%$ compared with the control. [Beitr. Tabakforsch. Int. 26 (2014) 176-182]

KEY WORDS: Triethyl citrate, cellulose acetate filter rod, plasticizer, acetate-paper dual filter rod, Virginia type cigarette.

\section{ZUSAMMENFASSUNG}

Bei der Vorbereitung von Zigarettenfilterstäben wurde in zwei verschiedenen Ansätzen Triethylcitrat (TEC) aufgebracht. Einer davon war die Verwendung von TEC als Weichmacher, welcher auf die Oberfläche von Celluloseacetatfasern (CA-Fasern) aufgesprüht wurde. Im zweiten Ansatz wurde TEC als Zusatzstoff zur Beschichtung des Zellulosepapiers von Acetat-Papier-Dualfiltern verwendet. Dazu wurden drei Arten von Zigarettenfilterstäben hergestellt: TEC-CA-Filterstäbe, TEC-CA-Papier-Dualfilterstäbe und CA-Papier-TEC-Dualfilterstäbe. Um das Aushärten der CA-Filterstäbe zu begünstigen, wurde Hochfrequenzstrahlung in das Verfahren zur Filterherstellung aufgenommen. Dann wurden Zigaretten mit Tabak der Sorte Virginia hergestellt und mit den drei Arten von vorbereiteten Filterstäben kombiniert. Anschließend wurde die Abscheideleistung von Phenolen aus dem Zigarettenhauptstromrauch untersucht. Die Ergebnisse zeigten, dass, unabhängig davon, wo das Triethylcitrat als Weichmacher oder als Additiv zur Beschichtung aufgebracht wurde, der Gehalt von Phenol, $o$-, $m$ - und $p$-Cresol im Hauptstromrauch von Zigaretten stark reduziert werden konnte. Die optimale Abscheideleistung für Phenol betrug im Vergleich zur Kontrolle 50\%. [Beitr. Tabakforsch. Int. 26 (2014) 176-182] 


\section{RESUME}

Le citrate de triéthyle (CTE) a été utilisé dans la préparation des tiges de filtres pour cigarettes selon deux approches. L'une consistait à utiliser le CTE comme plastifiant pulvérisé sur la surface des fibres en acétate de cellulose (AC). L'autre consistait à utiliser le CTE comme additif de revêtement sur le papier cellulosique des tiges de filtres doubles en papier à l'acétate. Trois types de tiges de filtres de cigarettes, à savoir des tiges de filtres CTE-AC, des tiges de filtres doubles papier-CTE-AC et des tiges de filtres doubles AC-papier-CTE, ont été fabriqués. Afin de favoriser le séchage des tiges $\mathrm{AC}$, un rayonnement haute fréquence a été introduit dans la procédure de fabrication des filtres. Ensuite, des cigarettes à base de tabac de type Virginie, combinées avec les trois types de tiges de filtres préparés, ont été fabriquées et l'efficacité d'extraction des phénols du flux principal de la fumée de cigarette a été étudiée. Les résultats ont révélé que peu importe où le citrate de triéthyle était appliqué, comme plastifiant ou comme additif de revêtement, la teneur en phénols - orthocrésol, méta-crésol et para-crésol - dans le flux principal de la fumée de cigarette pouvait être considérablement diminué. L'efficacité optimale d'extraction des phénols était de 50\% comparé au témoin. [Beitr. Tabakforsch. Int. 26 (2014) 176-182]

\section{INTRODUCTION}

It is well known that the burning of tobacco produces abundant and complex smoke (1). Some components of the smoke are indeed undesirable and harmful to human health and environment $(2,3)$. Among these troublesome constituents are phenols. The most abundant phenols in cigarette mainstream smoke are catechol, hydroquinone, phenol, $o-$, $m$ - and $p$-cresol and resorcinol $(4,5)$. These compounds have been reported as contributors to the carcinogenic activity of mainstream smoke $(6,7)$ and are detrimental to cilia in bronchial tubes (8). It is well known that cellulose acetate (CA) filters have moderate adsorption capacity for some phenolic compounds in cigarette smoke (9), and filter plasticizer such as triacetin can lead to further improvement on removal of phenol $(10,11)$. It has been reported that the cigarette design affects the content of phenols in cigarette mainstream smoke (12). Some efforts have been attempted in order to selectively reduce the content of phenols in cigarette mainstream smoke. WYNDER originally reported that polyethylene glycol as additive in filters improved removal of phenol $(9,13)$. Additionally, it has been claimed that phenol in cigarette mainstream smoke could be removed by a grooved filter plugged with modified cellulose wrapper (14). Also, the addition of an interconnected porous material such as polyglycidyl methacrylate could selectively absorb phenol from cigarette mainstream smoke (15).

Triethyl citrate (TEC) is a popular plasticizer (16) and was proposed as a plasticizer in CA filters during the 1970s (17). In the 1980s, TEC was further investigated as a plasticizer in CA filters by Brown \& Williamson Tobacco Corporation and Philip Morris Company. In menthol cigarettes, TEC delivered more menthol in smoke than when triacetin was the plasticizer $(18,19)$. At the same time, Brown \& Williamson Tobacco Corporation investigated the effect of TEC on the hardness of CA filter rods and revealed that the curing time of CA filter rods was prolonged (20). To the best of our knowledge, no other comprehensive investigation concerning the application of TEC as plasticizer for filter rods has been reported. And so far, TEC has not been applied in cigarette filter manufacture on a large scale. This paper describes two ways of TEC application in cigarette filter manufacture. One is to be applied as a plasticizer by spraying onto the surface of cellulose fibers. The other is to be applied as an additive by coating onto the cellulosic paper of filter rods. Thus, three types of filter rods, namely, TEC-CA filter rods, TEC-CA-P dual filter rods and CA-P-TEC dual filter rods, were manufactured. The filter rods were used to manufacture Virginia type cigarettes. The reduction of mainstream smoke phenols of the experimental cigarettes was investigated and the results are reported here. Furthermore, an innovative method was introduced to effectively improve the hardness of the TEC-CA filter rods in a short time.

\section{EXPERIMENTAL}

\section{Manufacture of TEC-CA filter rods}

The preparation of TEC-CA filters rods was performed in Changsha Cigarette Manufacture Factory, Changsha, China. All filter rods were manufactured by a KDF4 filter maker (Hauni Maschinenbau AG, Hamburg, Germany). TEC (FCC, purchased from Aladdin Industrial Corporation, Shanghai, China) was applied as plasticizer and was sprayed onto the surface of the filament (3.0Y/32000, supplied by Celanese Corporation, VA, USA). The filter wrap paper (supplied by Mudanjiang Hengfeng Paper Co., Ltd., Mudanjiang, China) was high porosity paper with $12000 \mathrm{CU}$ permeability. The manufacturing procedure was similar to the traditional procedure for CA filter rods in which triacetin was applied as plasticizer. The rods were $100 \mathrm{~mm}$ in length and $24 \mathrm{~mm}$ in circumference. The loading of plasticizer in the TEC-CA filter rods was adjusted within the range of 3-15\% (weight ratio of TEC/(TEC + CA filament)) and the prepared TEC-CA filter rods were designated TEC-CA-1 through 6 . Traditional CA filter rods with $8 \%$ triacetin (food grade, purchased from Aladdin Industrial Corporation, Shanghai, China) as plasticizer were selected as control rods.

Manufacture of acetate-paper dual filter rods/General methods of manufacture of acetate-paper dual filter rods

The acetate-paper dual filter rods were fabricated using a MULFI-E modular multi-filter maker (Hauni Maschinenbau AG, Hamburg, Germany) in Furong Daya Acetate Fiber Co. Ltd., Changde, China. The CA base rods were manufactured by a KDF2 filter maker (Hauni Maschinenbau AG, Hamburg, Germany). The paper base rods were manufactured by a ZL21 filter maker (Xuchang Fengyida Machinery Manufacturing Co. Ltd., Xuchang, China). The base rods were $120 \mathrm{~mm}$ in length and $23.5 \mathrm{~mm}$ in circumference. The filament was $3.0 \mathrm{Y} / 32000$. The control dual 
acetate-paper filter rods were obtained by combining traditional CA base rods with triacetin and paper base rods without the coating of TEC.

\section{Preparation of TEC-CA-paper dual filter rods}

The TEC-CA-paper dual filter rod was manufactured by combining a portion of CA base rod with TEC and a portion of paper base rod. The loading of TEC in the CA base rods was adjusted within the range of $7-16 \%$ (weight ratio of TEC/(TEC + CA filament)). The cellulosic paper which was used to manufacture paper base rods was supplied by Benkert Co. Ltd., Zhejiang, China. The acetate portion and the paper portion were combined by filter combiner with $12000 \mathrm{CU}$ porosity wrap paper to obtain the dual filter rods. The dual filter rods were designated TECCA-P-1 through 4 according to the loading of TEC in CA base rods.

\section{Preparation of CA-paper-TEC dual filter rods}

The CA base rods were conventional rods with $120 \mathrm{~mm}$ in length and $23.5 \mathrm{~mm}$ in circumference, in which triacetin was utilized as plasticizer. The cellulosic paper which was applied to manufacture paper base rods was coated with an ethanol solution of TEC at first, followed by the volatilization of solvent in strong air flow. Two levels of TEC loading on the cellulosic paper were investigated. Then the TEC-coated cellulosic paper was utilized to manufacture paper base rod. The acetate portion and the paper portion were then combined by filter combiner with $12000 \mathrm{CU}$ porosity wrap paper to obtain CA-paper-TEC dual filter rods. The dual filter rods were named CA-P-TEC-1 and CA-P-TEC-2, respectively.

\section{Hardness measurement of filter rods}

Hardness measurements of all prepared filter rods were performed on a Borgwaldt Hardness Tester (Borgwaldt KC, $\mathrm{GmbH}$, Hamburg, Germany). The diameter of the filter rod (DR) was initially measured with a diameter measuring device. Then a crushing load was applied and the remaining diameter (DL) was measured after a given time. The hardness was calculated as: $\% \mathrm{H}=(\mathrm{DL} / \mathrm{DR}) 100$ (21). Hardness of all tested filter rods was investigated.

\section{Accelerating the curing of CA rods treated with TEC by} high-frequency radiation

A high-frequency radiation device was designed and incorporated into the channel of the filter rod storage cabinet. The schematic drawing of the device is shown in Figure 1. The device was composed of a pair of positive and negative plates while the positive plate was connected with a sealed high-frequency electromagnetic launcher. The whole region was shielded with protective panels. The length of the plates imbedded in the channel was $400 \mathrm{~mm}$ and the time for the filter rods to pass through the device could be adjusted within the range of 10 to $60 \mathrm{~s}$. The oscillation frequency of the radiation was $13 \mathrm{MHz}$. The TEC-CA filter rods obtained from the forming machine were directly sent to the high-frequency radiation region by conveyer belt. The polar molecules in the filter rods were activated by the high-frequency electric field and generate heat energy to heat the filter rods. As a result, the rods were quickly cured and could be real-time launched to the cigarette maker.

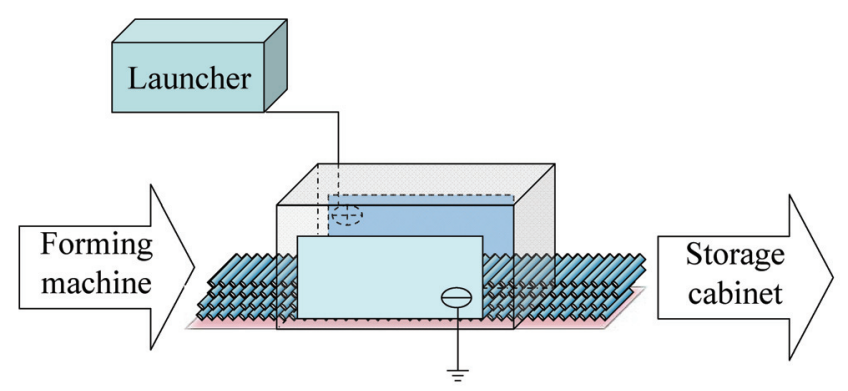

Figure 1. Schematic drawing of the high-frequency radiation device.

\section{Manufacture of cigarettes}

Cigarettes were fabricated in Changsha Cigarette Manufacture Factory. Cigarettes with $84 \mathrm{~mm}$ in length and $24 \mathrm{~mm}$ in circumference were made from Virginia (flue-cured) tobacco and different kinds of tested filter rods. The tobacco rod was $59 \mathrm{~mm}$ in length and the filter tip was $25 \mathrm{~mm}$ in length. For dual filter, the $10 \mathrm{~mm}$ paper portion was adjacent to the tobacco column while the $15 \mathrm{~mm} \mathrm{CA}$ portion was at the mouth-end. The cigarettes with TEC-CA filter rods, TEC-CA-P filter rods and CA-P-TEC filter rods were designated as C-TEC-CA-1 through 6, C-TEC-CA-P1 through 4 and C-CA-P-TEC-1 or -2 , respectively.

\section{Analysis of cigarette mainstream smoke}

The cigarettes were conditioned at $22 \pm 2{ }^{\circ} \mathrm{C}$ under $60 \pm 5 \%$ relative humidity for $48 \mathrm{~h}$ prior to the analysis of cigarette mainstream smoke.

\section{Analysis of TPM , nicotine, $\mathrm{H}_{2} \mathrm{O}$ and $\mathrm{CO}$}

All smoke collections were performed on a Borgwaldt RM200A smoking machine (Borgwaldt $\mathrm{KC} \mathrm{GmbH}$, Hamburg, Germany). Cigarette smoking was carried out in accordance with ISO Standard 3308 (22). The cigarette mainstream smoke was passed through a 92-mm Cambridge filter pad (GE Healthcare UK Ltd., Buckinghamshire, UK) for TPM collection. The content of CO in the mainstream smoke was analyzed according to the method recommended by CORESTA (23). The Cambridge filter pad was extracted in a flask with extraction solvent comprised of isopropanol, ethanol and $n$-heptadecane as internal standard. All reagents were of analytic grade. The flask was shaken on an oscillator for $30 \mathrm{~min}$, and then the extraction mixture was analyzed by gas chromatography following ISO Standard 4387 to measure total and nicotine-free dry particulate matter (24). 
Analysis of phenolic compounds of cigarette mainstream smoke

The cigarette mainstream smoke was collected by a 44-mm Cambridge filter pad (GE Healthcare UK Ltd., Buckinghamshire, UK) on a Cerulean SM450 smoking machine (Molins PLC, London, UK) according to ISO Standard 3308 (22). The filter pad was then extracted using $40 \mathrm{~mL}$ of $1 \%$ aqueous acetic acid. A $2-\mathrm{mL}$ aliquot of the extract was filtered on a $0.45-\mu \mathrm{m}$ PVDF filter. Finally, the samples were transferred to HPLC vials and analyzed by reverse phase gradient liquid chromatography with selective fluorescence detection. Quantitative determination was obtained using an external standard method. The following seven phenolic compounds, namely hydroquinone, resorcinol, catechol, phenol, $m$-cresol, $p$-cresol, and $o$-cresol were characterized according to China Standard YC/T 2552008 (25). All standard substances were purchased from J\&K Chemical, Beijing, China.

\section{RESULTS AND DISCUSSION}

\section{Investigating of tested filter rod hardness}

All TEC-CA filter rods with different loading of plasticizer were cured for one hour and then their hardness was measured. The data and other physical parameters of the rods are shown in Table 1.

Table 1. The parameters of the TEC-CA filter rods.

\begin{tabular}{|c|c|c|c|c|c|c|}
\hline $\begin{array}{l}\text { Filter } \\
\text { sample }\end{array}$ & $\begin{array}{c}\text { PZ level } \\
(\%)\end{array}$ & $\begin{array}{l}W^{b} \\
(\mathrm{mg})\end{array}$ & $\begin{array}{l}\mathrm{CC}^{\mathrm{C}} \\
(\mathrm{mm})\end{array}$ & $\begin{array}{l}\text { OVAL } \\
(\mathrm{mm})\end{array}$ & $\begin{array}{l}\mathrm{PD}^{\mathrm{d}} \\
(\mathrm{Pa})\end{array}$ & $\begin{array}{l}\mathrm{HD}^{\mathrm{e}} \\
(\%)\end{array}$ \\
\hline Control-1 & $8.3\left(\mathrm{TA}^{\mathrm{f}}\right)$ & 606 & 24.0 & 0.31 & 2685 & 83 \\
\hline TEC-CA-1 & 3.2 & 564 & 24.0 & 0.36 & 2597 & 73 \\
\hline TEC-CA-2 & 5.8 & 579 & 24.0 & 0.33 & 2587 & 75 \\
\hline TEC-CA-3 & 8.1 & 603 & 24.0 & 0.35 & 2675 & 75 \\
\hline TEC-CA-4 & 10.5 & 610 & 24.0 & 0.33 & 2656 & 75 \\
\hline TEC-CA-5 & 12.7 & 625 & 24.0 & 0.31 & 2666 & 76 \\
\hline TEC-CA-6 & 14.8 & 641 & 24.0 & 0.34 & 2695 & 73 \\
\hline
\end{tabular}

a-f PZ level: plasticiser level; WT: weight; CC: circumference; PD: pressure drop; HD: hardness; TA: triacetin

From Table 1, it is observed that, within one hour of curing time, the TEC-CA filter rods were much softer than the control filter rods. The level of hardness of the tested rods was similar to that of cellulose acetate filter rods without plasticizer. In order to confirm the plasticizing effect of TEC, longer curing time was investigated. The corresponding hardness of the tested rods at different curing times are shown in Table 2.

From Table 2, it can be seen that the hardness of the tested filter rods exhibits an increasing trend with the prolonged curing time except rod TEC-CA-1, in which too little TEC was added to plasticize the CA fibers. Obviously, TEC can fulfill the role of plasticizer. The hardness of TEC-CA-3 through 6 could attain $85 \%$ after forty-eight hours of curing time. However, a higher level of hardness could not be obtained even though the loading of plasticizer was increased from $8.1 \%$ to $14.8 \%$.
Table 2. The hardness (HD) of the tested rods in different curing time.

\begin{tabular}{l|c|c|c|c|c}
\hline $\begin{array}{l}\text { Filter } \\
\text { sample }\end{array}$ & $\begin{array}{c}\mathrm{HD}(\%) \\
1 \mathrm{~h}\end{array}$ & $\begin{array}{c}\mathrm{HD}(\%) \\
2 \mathrm{~h}\end{array}$ & $\begin{array}{c}\mathrm{HD}(\%) \\
4 \mathrm{~h}\end{array}$ & $\begin{array}{c}\mathrm{HD}(\%) \\
24 \mathrm{~h}\end{array}$ & $\begin{array}{c}\mathrm{HD}(\%) \\
48 \mathrm{~h}\end{array}$ \\
\hline Control-1 & 83 & 85 & 86 & 88 & 88 \\
TEC-CA-1 & 73 & 74 & 75 & 76 & 76 \\
TEC-CA-2 & 75 & 78 & 78 & 82 & 82 \\
TEC-CA-3 & 75 & 78 & 79 & 84 & 85 \\
TEC-CA-4 & 75 & 78 & 80 & 83 & 85 \\
TEC-CA-5 & 76 & 79 & 80 & 83 & 85 \\
TEC-CA-6 & 73 & 77 & 80 & 84 & 85 \\
\hline
\end{tabular}

The hardness and other parameters of acetate-paper dual filter rods were measured three days after their manufacturing because of a consigned process. The hardness and other physical parameters of all rods are shown in Table 3.

The data in Table 3 showed that the hardness of all filter rods is higher than $85 \%$. The hardness and pressure drop of the tested rods were the same as the control rods.

Table 3. The parameters of the dual filter rods.

\begin{tabular}{l|c|c|c|c|c|c}
\hline $\begin{array}{l}\text { Filter } \\
\text { sample }\end{array}$ & $\begin{array}{c}\mathrm{PZ} \mathrm{level}^{\mathrm{a}}(\mathrm{\%}) \\
\text { ( }\end{array}$ & $\begin{array}{c}\text { Coated } \\
\text { weight } \\
(\mathrm{mg} / \mathrm{cig})\end{array}$ & $\begin{array}{c}\mathrm{WT}^{\mathrm{b}} \\
(\mathrm{mg})\end{array}$ & $\begin{array}{c}\mathrm{CC}^{\mathrm{c}} \\
(\mathrm{mm})\end{array}$ & $\begin{array}{c}\mathrm{PD}^{\mathrm{d}} \\
(\mathrm{Pa})\end{array}$ & $\begin{array}{c}\mathrm{HD}^{\mathrm{e}} \\
(\%)\end{array}$ \\
\hline Control-2 & $7.6{\left(\mathrm{TA}^{\mathrm{f}}\right)}^{\mathrm{f}}$ & - & 743 & 24.0 & 3028 & 88 \\
TEC-CA-P-1 & 7.0 & - & 730 & 24.0 & 2911 & 87 \\
TEC-CA-P-2 & 10.2 & - & 744 & 24.0 & 2999 & 89 \\
TEC-CA-P-3 & 12.8 & - & 746 & 24.0 & 2969 & 90 \\
TEC-CA-P-4 & 16.1 & - & 764 & 24.0 & 2999 & 91 \\
CA-P-TEC-1 & $7.6(\mathrm{TA})$ & 10 & 816 & 24.0 & 2734 & 85 \\
CA-P-TEC-2 & $7.6(\mathrm{TA})$ & 20 & 815 & 24.0 & 2911 & 88 \\
\hline
\end{tabular}

a-f PZ level: plasticiser level; WT: weight; CC: circumference PD: pressure drop; HD: hardness; TA: triacetin

\section{Improving the hardness of CA filter rods}

Hardness is a quality indicator for cigarette filter rods. Too soft filter rods result in the jamming of the emission channel and result in more waste rods. More seriously, it leads to the collapse of produced cigarettes. In order to accelerate the curing procedure and meet the need of direct use of filter rods in cigarette manufacture, TEC-CA filter rods obtained from the forming machine were directly sent to the channel imbedded with a high-frequency radiation device by conveyer belt. The radiation time was set as 20 , $30,40,50$ and $60 \mathrm{~s}$, respectively. The hardness of the rods was monitored by a hardness tester (Borgwaldt $\mathrm{KC} \mathrm{GmbH}$, Hamburg, Germany) and the results are described in Figure 2. It could be concluded that high-frequency radiation can effectively accelerate the curing process of TEC$\mathrm{CA}$ rods and improve the hardness of the rods within a short time. The hardness of the rods was greatly improved when the radiation time was increased from 20 to $50 \mathrm{~s}$. However, when the radiation time was greater than $50 \mathrm{~s}$, the improvement of the hardness was diminished. Generally, satisfactory hardness could be obtained for the samples by $50 \mathrm{~s}$ of high-frequency radiation except for sample TECCA-1. 


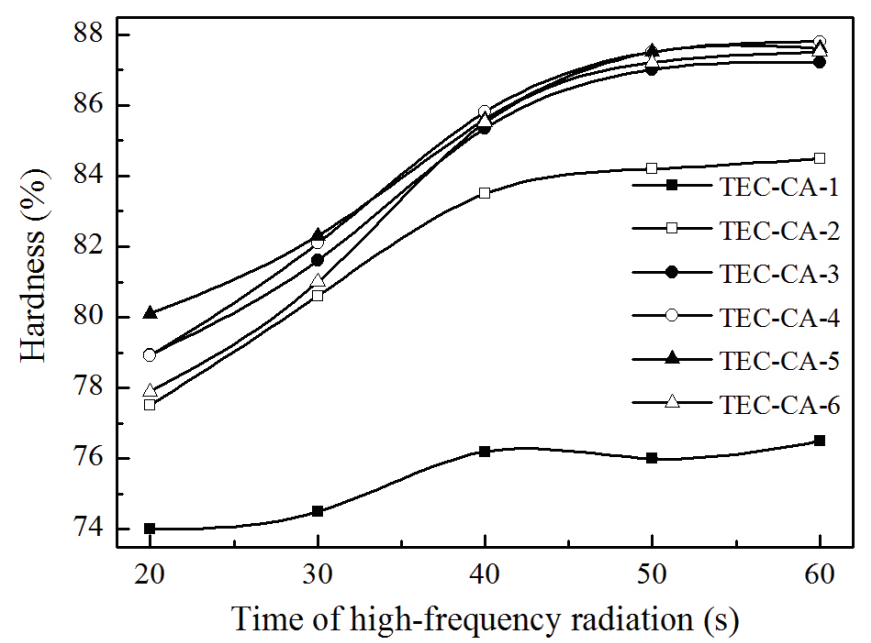

Figure 2. Effect of high-frequency radiation time on the hardness of TEC-CA filter rods.

\section{Routine analysis of cigarette mainstream smoke}

Routine analysis of cigarette mainstream smoke, including total particulate matter (TPM), nicotine, $\mathrm{H}_{2} \mathrm{O}$ and $\mathrm{CO}$, of all the prepared cigarettes was performed, and then the nicotine- and humectant-free dry particulate matter (NHFDPM, also named "tar") could be obtained. The results of the analysis are listed in Table 4. It can be seen that there is no significant difference in the content of TPM, "tar", nicotine, $\mathrm{H}_{2} \mathrm{O}$ and $\mathrm{CO}$ between the test cigarettes and the controls.

Table 4. Routine analysis of the tested cigarettes.

\begin{tabular}{l|cc|c|c|c}
\hline Cigarette sample & $\begin{array}{c}\text { TPM } \\
(\mathrm{mg} / \mathrm{cig})\end{array}$ & $\begin{array}{c}\text { Nicotine } \\
(\mathrm{mg} / \mathrm{cig})\end{array}$ & $\begin{array}{c}\mathrm{H}_{2} \mathrm{O} \\
(\mathrm{mg} / \mathrm{cig})\end{array}$ & $\begin{array}{c}\text { "Tar" } \\
(\mathrm{mg} / \mathrm{cig})\end{array}$ & $\begin{array}{c}\mathrm{CO} \\
(\mathrm{mg} / \mathrm{cig})\end{array}$ \\
\hline C-Control-1 & 13.1 & 0.99 & 2.2 & 9.9 & 10.0 \\
C-TEC-CA-1 & 13.5 & 0.99 & 2.4 & 10.1 & 10.1 \\
C-TEC-CA-2 & 13.1 & 0.95 & 2.3 & 9.9 & 10.7 \\
C-TEC-CA-3 & 13.4 & 0.97 & 2.5 & 9.9 & 10.1 \\
C-TEC-CA-4 & 13.1 & 0.96 & 2.3 & 9.8 & 11.2 \\
C-TEC-CA-5 & 13.3 & 0.95 & 2.3 & 10.1 & 11.2 \\
C-TEC-CA-6 & 12.8 & 0.95 & 2.2 & 9.7 & 10.9 \\
C-Control-2 & 10.5 & 0.76 & 0.9 & 8.8 & 11.0 \\
C-TEC-CA-P-1 & 9.9 & 0.73 & 1.1 & 8.1 & 10.8 \\
C-TEC-CA-P-2 & 10.6 & 0.76 & 1.1 & 8.7 & 11.2 \\
C-TEC-CA-P-3 & 10.0 & 0.73 & 1.1 & 8.2 & 10.9 \\
C-TEC-CA-P-4 & 9.6 & 0.72 & 1.0 & 7.9 & 10.9 \\
C-CA-P-TEC-1 & 10.6 & 0.76 & 1.0 & 8.8 & 10.8 \\
C-CA-P-TEC-2 & 9.4 & 0.73 & 0.9 & 7.8 & 10.6 \\
\hline
\end{tabular}

Reduction of phenolic compounds in the cigarette mainstream smoke by TEC

The content of several main phenolic compounds in the mainstream smoke of tested cigarettes was investigated and the data are listed in Table 5. It can be seen that, except for C-TEC-CA-1 in which the loading of plasticizer is only $3 \%$, TEC exhibited a special ability to reduce the content of monophenols in the cigarette mainstream smoke. The removal efficiency of monophenols from cigarette mainstream smoke compared with the control cigarette is shown in Figure 3 for the cigarettes with CA filters and in Figure 4

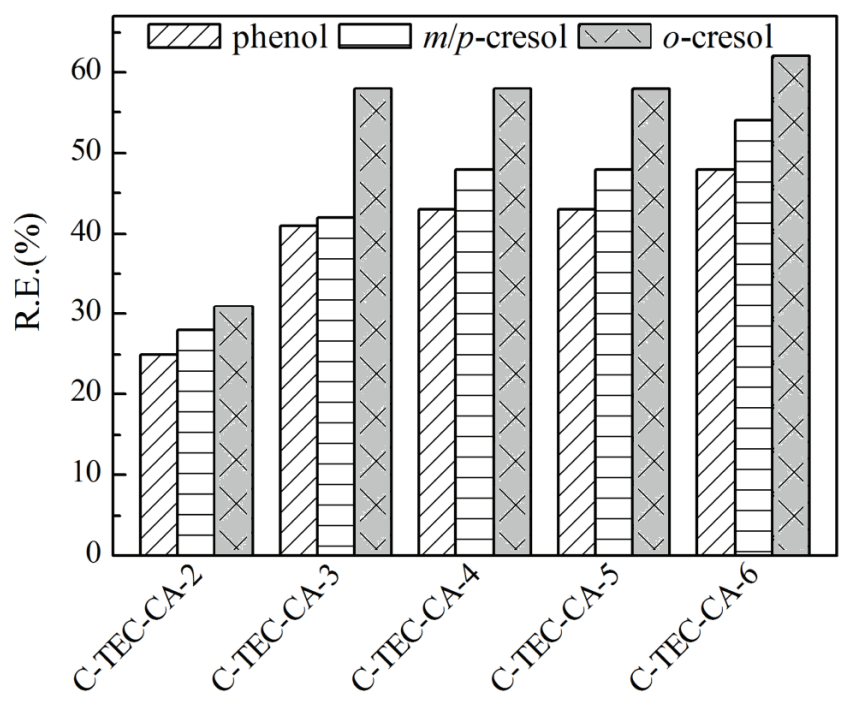

Figure 3. Removal efficiency of monophenols from the cigarette mainstream smoke with CA filters.

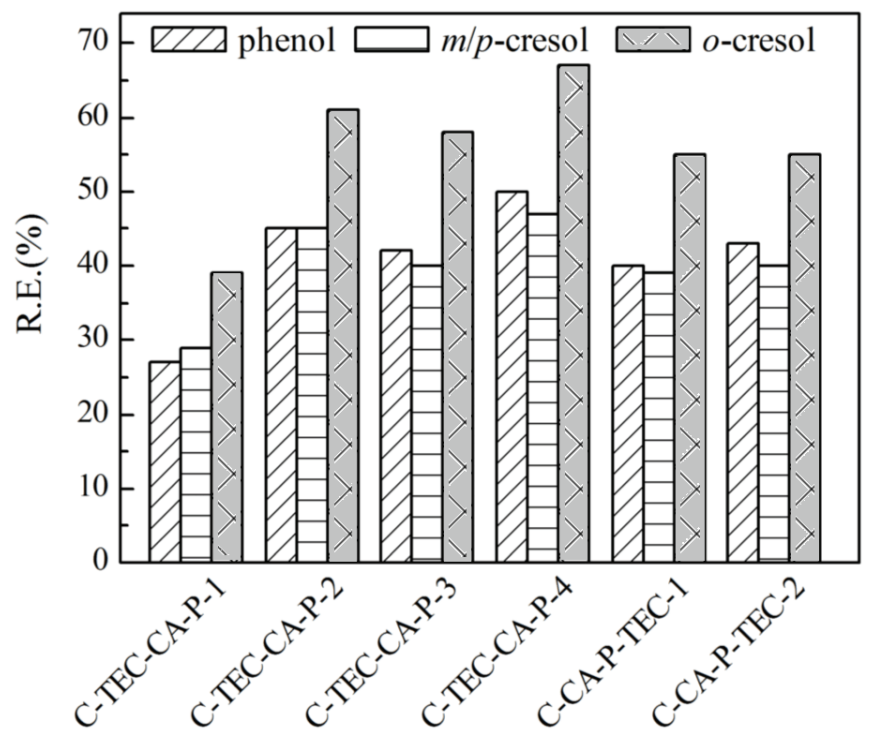

Figure 4. Removal efficiency of monophenols from the cigarette mainstream smoke with acetate-paper dual filters.

for the cigarettes with acetate-paper dual filters. In the CA filter cigarettes, the removal efficiency of phenol ranged from $25 \%$ to $48 \%$ except for C-TEC-CA-1, and the removal efficiency of $o-, m$ - and $p$-cresol is similar or greater. In the dual-filter cigarettes, the removal efficiency of phenol was at least $27 \%$. However, due to their lower vapor pressure, other phenolic compounds such as hydroquinone, resorcinol and catechol were not significantly changed by the tested filters. Additionally, TEC as a coating additive similarly exhibited the special adsorption for monophenols, and the removal efficiency of phenol was greater than $40 \%$. The removal efficiency of monophenols was affected by the loading of TEC in the filter rods. However, when the loading of TEC reached a certain level, the monophenol removal efficiency would exhibit a little fluctuation. This implied that it was futile for selective adsorption to phenols in cigarette mainstream smoke by means of excess loading 
Table 5. The content of phenolic compounds in cigarette mainstream smoke.

\begin{tabular}{l|c|c|c|c|c|c}
\hline Cigarette sample & $\begin{array}{c}\text { Hydroquinone } \\
(\mu \mathrm{g} / \mathrm{cig})\end{array}$ & $\begin{array}{c}\text { Resorcinol } \\
(\mu \mathrm{g} / \mathrm{cig})\end{array}$ & $\begin{array}{c}\text { Catechol } \\
(\mu \mathrm{g} / \mathrm{cig})\end{array}$ & $\begin{array}{c}\text { Phenol } \\
(\mu \mathrm{g} / \mathrm{cig})\end{array}$ & $\begin{array}{c}\mathrm{m} / \mathrm{p} \text {-Cresol } \\
(\mu \mathrm{g} / \mathrm{cig})\end{array}$ & $\begin{array}{c}o \text {-Cresol } \\
(\mu \mathrm{g} / \mathrm{cig})\end{array}$ \\
\hline C-Control-1 & 48.7 & 1.9 & 60.4 & 11.5 & 10.1 & 2.6 \\
C-TEC-CA-1 & 50.0 & 1.7 & 57.4 & 13.3 & 10.5 & 2.8 \\
C-TEC-CA-2 & 42.1 & 1.6 & 54.7 & 8.6 & 7.3 & 1.8 \\
C-TEC-CA-3 & 44.6 & 1.7 & 58.3 & 6.8 & 5.9 & 1.1 \\
C-TEC-CA-4 & 42.6 & 1.5 & 54.3 & 6.5 & 5.3 & 1.1 \\
C-TEC-CA-5 & 44.1 & 1.6 & 56.5 & 6.6 & 5.3 & 1.1 \\
C-TEC-CA-6 & 44.2 & 1.5 & 55.1 & 6.0 & 4.6 & 1.0 \\
C-Control-2 & 41.4 & 1.5 & 54.3 & 13.2 & 9.7 & 3.3 \\
C-TEC-CA-P-1 & 40.3 & 1.5 & 51.8 & 9.6 & 6.9 & 2.0 \\
C-TEC-CA-P-2 & 41.0 & 1.5 & 51.8 & 7.2 & 5.3 & 1.3 \\
C-TEC-CA-P-3 & 42.3 & 1.5 & 54.3 & 7.6 & 5.8 & 1.4 \\
C-TEC-CA-P-4 & 42.2 & 1.5 & 53.9 & 6.6 & 5.1 & 1.1 \\
C-CA-P-TEC-1 & 41.8 & 1.5 & 54.5 & 7.9 & 5.9 & 1.5 \\
C-CA-P-TEC-2 & 37.0 & 1.4 & 49.1 & 7.5 & 5.8 & 1.5 \\
\hline
\end{tabular}

of TEC. Instead, it would damage the forming of filter rods and cigarettes. Our investigation results indicated that the loading of plasticizer with TEC should range between $8 \%$ and $10 \%$, and $10 \mathrm{mg} / \mathrm{cig}$ of loading was suitable when TEC was a loading additive. The optimal performance of the tested cigarettes happened in C-TEC-CA-P-4 with a removal efficiency of $50 \%$ and $67 \%$ for phenol and $\mathrm{m} / \mathrm{p}$ cresol, respectively, while C-TEC-CA- 6 exhibited the best removal efficiency for $o$-cresol (54\%).

\section{CONCLUSIONS}

In summary, TEC was successfully applied as a filter plasticizer or as coating additive in Virginia type cigarette manufacture. The application of TEC as plasticizer to prepare CA filter rods is feasible under the assistance of high-frequency radiation. The cigarette manufacture process would not be affected if TEC was applied as additive to be coated onto the cellulosic paper to prepare dual filter rods. The monophenols of cigarette mainstream smoke could be reduced by TEC no matter whether it was used as a plasticizer or coating additive. Further studies on cigarette taste and industrial production with TEC will be carried out in the near future.

\section{ACKNOWLEDGMENT}

This work was supported by Project 2012-JC-0009 from China Tobacco Hunan Industry Co., Ltd.

\section{REFERENCES}

1. Rodgman, A. and T.A. Perfetti: The Chemical Components of Tobacco and Tobacco Smoke; CRC Press, Boca Raton, Florida, USA, 2009.

2. Fowles, J. and E. Dybing: Application of Toxicological Risk Assessment Principles to the Chemical Constituents of Cigarette Smoke; Tob. Control 12 (2003) 424-430.

3. Green, C.R., J.N. Schumacher, R.A. Lloyd, and A.
Rodgman: Comparison of the Composition of Tobacco Smoke and the Smokes From Various Tobacco Substitutes; Beitr. Tabakforsch. Int. 22 (2007) 258-289.

4. Dyakonov, A.J., R.T. Walker, C.A. Brown, F.R. Perini, D.S. Passer, J. Guan, and E.A. Robinson: Studies of Formation of Smoke Phenols; Beitr. Tabakforsch. Int. 23 (2008) 68-84.

3. Green, C.R., J.N. Schumacher, R.A. Lloyd, and A. Rodgman: Comparison of the Composition of Tobacco Smoke and the Smokes From Various Tobacco Substitutes; Beitr. Tabakforsch. Int. 22 (2007) 258-289.

4. Dyakonov, A.J., R.T. Walker, C.A. Brown, F.R. Perini, D.S. Passer, J. Guan, and E.A. Robinson: Studies of Formation of Smoke Phenols; Beitr. Tabakforsch. Int. 23 (2008) 68-84.

5. Risner, C.H. and S.L. Cash: A High-Performance Liquid Chromatographic Determination of Major Phenolic Compounds in Tobacco Smoke; J. Chromatogr. Sci. 28 (1990) 239-244.

6. Poirier, M., M. Fournier, P. Brousseau, and A. Morin: Effects of Volatile Aromatics, Aldehydes, and Phenols in Tobacco Smoke on Viability and Proliferation of Mouse Lymphocytes; J. Toxic. Environ. Health A 65 (2002) 1437-1451.

7. Wynder, E.L. and D. Hoffmann: A Study of Tobacco Carcinogenesis. VIII. The Role of the Acidic Fractions as Promoters; Cancer 14 (1961) 1306-1315.

8. Wynder, E.L., H.E. Kaiser, D.A. Goodman, and D. Hoffmann: A Method for Determining Ciliastatic Components in Cigarette Smoke; Cancer 16 (1963) 1222-1225.

9. Hoffmann, D. and E.L. Wynder: Filtration of Phenols From Cigarette Smoke; J. Natl. Cancer Inst. 30 (1963) 67-84.

10. Le Roux, J.H.: The Selective Retention of Phenol by Cigarette Filter Materials; Beitr. Tabakforsch. 3 (1965) 157-167.

11. Cuzin J., A. Testa, and P. Testa: Selective Retention of Some Smoke Condensate Components: Phenols, Polyphenols, Heterocyclic $N$-Compounds (Die selektive Retention bestimmter chemischer Bestandteile des Kondensates: Phenole, Polyphenole, heterocyclische 
Stickstoffverbindungen); Beitr. Tabakforsch. 3 (1965) 215-219.

12. Dagnon, S., A. Stoilova, I. Ivanov, and S. Nikolova: The Effect of Cigarette Design on the Content of Phenols in Mainstream Tobacco Smoke; Beitr. Tabakforsch. Int. 24 (2011) 187-193.

13. Mumpower, R.C. and G.P. Touey: Selective Removal of Phenol From Cigarette Smoke With Filters; Kingsport, Tennessee, 1965, Bates-No. 950154260950154269, available at: http://legacy.library.ucsf.edu/ tid/psm54f00/pdf (accessed November 2014).

14. Huang, F., Y. Jin, K.J. Zhong, X.Q. Zhu, Q. Liu, and L.Y. Xie: Selective Removal of Phenol From Cigarette Smoke by Grooved Filter Plug with Modified Cellulose Wrapper; Tob. Sci. Tech. 7 (2012) 54-60.

15. Yang, S., C. Nie, X.H. Sun, Q.P. Yan, Y.P. Wang, L. Zhao, H.M. Liu, and X.B. Zhang: Interconnected Porous Material of Poly (Glycidyl Methacrylate) for Selectively Reducing Phenol in Cigarette Smoke; Tob. Sci. Tech. 8 (2012) 44-48.

16. Park, H.M., M. Misra, L.T. Drzal, and A.K. Mohanty: "Green" Nanocomposites From Cellulose Acetate Bioplastic and Clay: Effect of Eco-Friendly Triethyl Citrate Plasticizer; Biomacromolecules 5 (2004) 2281-2288.

17. L.W. Renfro: Plasticizer for Cellulose Acetate Cigarette Filters; Kingsport, Tennessee, 1987, BatesNo.508100885-508100903, available at: http://legacy. library.ucsf.edu/tid/czm51 f00/pdf(accessed November 2014).

18. Walker, L.A.: Effect of Triethyl Citrate Plasticizer on Cigarette Menthol Delivery; 1988, available at: http:// legacy.library.ucsf.edu/tid/lxu21 f00/pdf(accessed November 2014).

19. Finley, A.: Completion Report - Alternative Plasticizer; Philip Morris USA, Interoffice Correspondence to K. Newman, May 16, 1990, Bates-No. 2050790115-0123, available at: http://legacy.library.ucsf.edu/tid/lmr 89a00/pdf (accessed November 2014).

20. Crain, W.O., F.K. St.Charles, and L.L. Shockley: Hardness of Filter Rods with Triethyl Citrate; 1987, available at: http://legacy.library.ucsf.edu/tid/kyb30f00 Bates-No. 581102281-581102293 (accessed November 2014).
21. Colard, S.: Hardness Measurement on Cigarettes and Cigarette Filter Rods; CORESTA Technical Report, Sub-Group Physical Test Methods, March 2011, 1-9, available at: http://www.coresta.org/Reports/PTMTechRep-Hardness_Measurement_Cig_CigFilters March2011.pdf (accessed November 2014).

22. International Organization for Standardization (ISO): International Standard 3308:2000. Routine Analytical Cigarette Smoking Machine -- Definitions and Standard Conditions; ISO, Geneva, Switzerland, 2000.

23. CORESTA Recommended Method No. 5: Determination of Carbon Monoxide in the Mainstream Smoke of Cigarettes by Non-Dispersive Infrared Analysis; Cooperation Centre for Scientific Research Relative to Tobacco, 1993, available at http://coresta. org/Recommended_Methods/CRM_05.pdf (accessed November 2014).

24. International Organization for Standardization (ISO): International Standard 4387:2000. Cigarettes -- Determination of Total and Nicotine Free Dry Particulate Matter Using a Routine Analytical Smoking Machine; ISO, Geneva, Switzerland, 2000.

25. China Standard for Tobacco: YC/T 255-2008. Cigarettes - Determination of Major Phenolic Compounds in Mainstream Cigarette Smoke - High Performance Liquid Chromatographic Method; Standards Press of China, Beijing, China, 2008, available at http://www. freestd.us/soft4/3318375.htm (accessed November 2014).

\section{Corresponding author:}

Saibo $Y u$

Technology Center

China Tobacco Hunan Industry Co. Ltd. Changsha 410007

P.R. China

E-mail:yusb1125@hngytobacco.com 